\title{
STUDY OF MACRO-SEGREGATIONS IN A CONTINUOUSLY CAST BILLET
}

\author{
ŠTUDIJ MAKROIZCEJ V KONTINUIRNO ULITI GREDICI
}

\author{
Ladislav Socha $^{1}$, Vlastimil Vodárek ${ }^{2}$, Karel Michalek ${ }^{1}$, Hana Francová ${ }^{3}$, \\ Karel Gryc ${ }^{1}$, Markéta Tkadlečková ${ }^{1}$, Ladislav Válek ${ }^{4}$ \\ ${ }^{1}$ VŠB - Technical University of Ostrava, FMME, Department of Metallurgy and Foundry, 17. listopadu 15/2172, \\ 70833 Ostrava - Poruba, Czech Republic \\ ${ }^{2}$ VŠB - Technical University of Ostrava, FMME, Department of Material Engineering, 17. listopadu 15/2172, \\ 70833 Ostrava - Poruba, Czech Republic \\ ${ }^{3}$ VŠB - Technical University of Ostrava, FMME, Department of Physical Chemistry and Theory of Technological Processes, \\ 17. listopadu 15/2172, 70833 Ostrava - Poruba, Czech Republic \\ ${ }^{4}$ ArcelorMittal Ostrava a.s., Research, Vratimovská 689, 70702 Ostrava-Kunčice, Czech Republic \\ ladislav.socha@vsb.cz \\ Prejem rokopisa - received: 2015-07-13; sprejem za objavo - accepted for publication: 2016-02-09
}

doi:10.17222/mit.2015.220

\begin{abstract}
This paper is devoted to the study of macro-segregations on the longitudinal section of a continuously cast billet $\varnothing 160 \mathrm{~mm}$ destined for the production of seamless pipes. Its evaluation comprised a visual inspection of macro-etching, microstructure characterisation and a quantitative X-ray microanalysis by means of an energy-dispersive X-ray microanalysis (EDX) in the selected areas. Furthermore, segregation parameters were calculated using combustion-analysis data. The results given in this paper present the basic information about the interior structure of a continuously cast billet. The results will be used, beside other things, for the verification of the results of the numerical modelling of continuously cast billets.

Keywords: steel, macro-segregation, continuous casting, round billet
\end{abstract}

Ta članek obravnava študij makro-izcej na vzdolžnem prerezu kontinuirno ulite gredice $\varnothing 160$ mm namenjene za proizvodnjo brezšivnih cevi. Ocena je sestavljena iz vizuelnega pregleda po makrojedkanju, iz ocene in kvantitativne rentgenske mikroanalize s pomočjo energijsko disperzijske rentgenske analize (EDX) izbranih področij. Izračunani so bili tudi parametri izcejanja s pomočjo podatkov zgorevne analize. Rezultati, prikazani v tem članku, predstavljajo osnovno informacijo o notranji strukturi v kontinuirno uliti gredici. Rezultati bodo uporabljeni, poleg drugega, tudi za preverjanje rezultatov numeričnega modeliranja kontinuirno ulitih gredic.

Ključne besede: jeklo, makro-izceja, kontinuirno ulivanje, okrogla gredica

\section{INTRODUCTION}

Steel crystallization occurs during the casting and subsequent solidification of continuously cast billets. Material solidification, the grain size, chemical heterogeneity and the existence of incompactness can have negative influences on the properties of the final material. ${ }^{1}$ A relatively big homogeneity of the distribution of sulphur and other elements and also the absence of thick segregate areas in the whole cross-section are due to the fast solidification of the billet. The range and removal of impurities are mainly connected with the contents of phosphorus and sulphur in the steel, the steel temperature and also the intensity of the billet cooling. ${ }^{2}$ The local chemical heterogeneity appears in the billet axis, especially for the steels with higher contents of carbon where the possibility of internal-hollow creation is higher. ${ }^{3,4}$

The paper presents the results of the study of macrosegregation on the longitudinal section of a continuously cast billet $\varnothing 160 \mathrm{~mm}$. Samples were taken during the casting of a high-quality billet destined for the production of seamless pipes without the usage of the MEMS technology. First, a visual inspection of the longitudinal section of the billet was made for the study of macrosegregation in a continuously cast billet. Then a microstructural analysis using a quantitative $\mathrm{X}$-ray microanalysis with the help of EDX in SEM (Quanta 450 FEG) was carried out. The results of the microstructural analysis were subsequently supplemented with an analysis of the contents of carbon and sulphur with the aim to evaluate the chosen segregation parameters for the micro-samples taken from particular areas of macroetching. The obtained original results will be, beside other things, used for verifying the results of numerical modelling of casting continuously cast billets.

\section{MACRO-STRUCTURAL ANALYSIS OF THE BILLET}

First, a visual inspection of the longitudinal section of the billet was made for the study of macro-segregation in the continuously cast billet, which is given in Figure 1a.

It is evident in Figure 1a that the surface area of equiaxed crystals (the chill zone) penetrates into a depth 

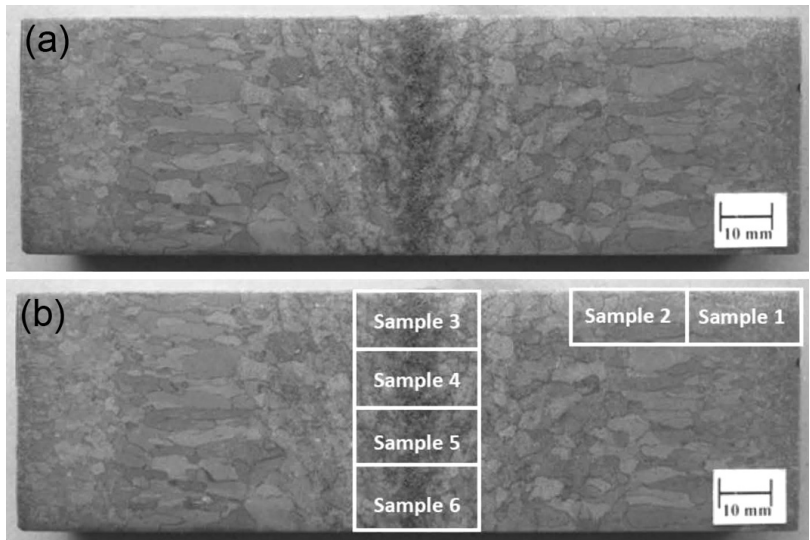

Figure 1: Longitudinal section through $\varnothing 160 \mathrm{~mm}$ billet: a) macroetching of the studied billet, b) positions of the samples taken for a microstructure characterisation

Slika 1: Vzdolžni prerez skozi gredico $\varnothing 160 \mathrm{~mm}$ : a) makrojedkana gredica, b) položaj vzorcev, vzetih za karakterizacijo mikrostrukture

of approx. $18 \mathrm{~mm}$. This is followed by an area of columnar crystals with a thickness of approx. $35 \mathrm{~mm}$ and, in the middle of the longitudinal section, there is an area of equiaxed grains.

In the axial area of the billet, there is shrinkage porosity that is a consequence of the casting conditions during the final period of the billet solidification. The darker contrast in the area of shrinkage porosity is related to the processes of chemical segregation during the solidification.

\section{MICROSTRUCTURAL ANALYSIS OF THE BILLET}

After the visual inspection of macro-etching, the sample was cut into smaller parts, evident in Figure 1b. The samples were prepared for a microstructural analysis aimed at evaluating the characterisation of the microstructure and chemical heterogeneity using the EDX technique. A few samples - sample 2, sample 4 and sample 5 - were chosen for the analysis. The following elements were chosen for the X-ray microanalysis

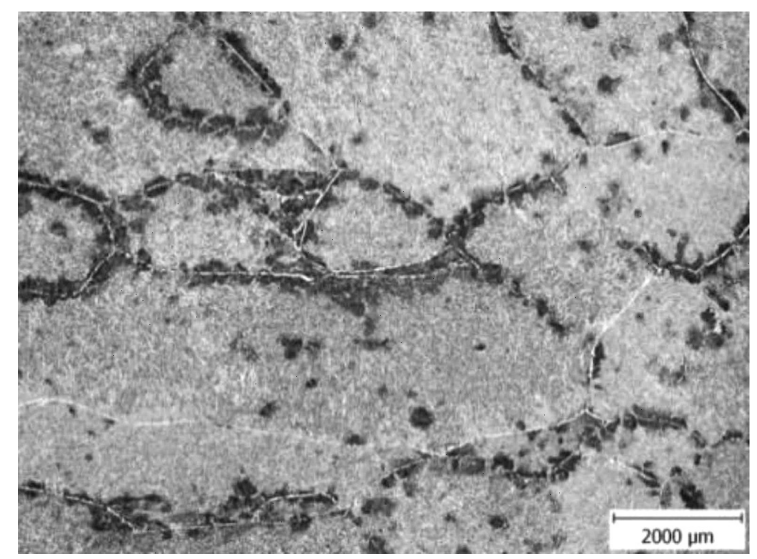

Figure 2: Microstructure in the area of columnar crystals Slika 2: Mikrostruktura področja s stebrastimi kristalnimi zrni
(EDX): silicon, phosphorus, chromium, manganese, iron and molybdenum. The results of a semi-quantitative $\mathrm{X}$-ray microanalysis were normalized to $100 \%$.

The microstructure of sample 2 presenting areas of columnar crystals is given in Figure 2. Previous austenite grain boundaries are decorated with fine grains of allotriomorphic ferrite. Nodules of the pearlite component usually grow up along the networks of allotriomorphic ferrite. The microstructure inside the austenitic grains consists of a mixture of acicular ferrite and a small fraction of pearlite, as it is evident in Figure 3.

Subsequently, a quantitative X-ray microanalysis (EDX) was made. A spectral RTG microanalysis of the matrix was made in the randomly chosen areas of sample 2 and the results are given in Table 1.

Table 1: Results of the EDX microanalysis - sample 2 Tabela 1: Rezultati EDX mikroanalize - vzorec 2

\begin{tabular}{|c|c|c|c|c|c|}
\hline \multirow{2}{*}{ Analysis } & \multicolumn{5}{|c|}{ Analysed elements $(w / \%)$} \\
\cline { 2 - 6 } & $\mathrm{Si}$ & $\mathrm{Cr}$ & $\mathrm{Mn}$ & $\mathrm{Fe}$ & $\mathrm{Mo}$ \\
\hline 1 & 0.30 & 0.72 & 1.01 & 97.47 & 0.50 \\
\hline 2 & 0.40 & 0.75 & 1.21 & 97.24 & 0.40 \\
\hline 3 & 0.36 & 0.78 & 0.90 & 97.66 & 0.30 \\
\hline AVE & $\mathbf{0 . 3 5}$ & $\mathbf{0 . 7 5}$ & $\mathbf{1 . 0 4}$ & $\mathbf{9 7 . 4 6}$ & $\mathbf{0 . 4 0}$ \\
\hline STD & 0.05 & 0.03 & 0.16 & 0.21 & 0.10 \\
\hline
\end{tabular}

Note: AVE - arithmetic mean, STD - standard deviation

The microstructure of sample 4 in the axial area of the billet, which shows an increased fraction of the pearlite component in the surroundings of the shrinkage porosity, is shown in Figure 4. Networks of allotriomorphic ferrite decorate the prior austenite grain boundaries. Austenite decomposed into a mixture of acicular ferrite and pearlite inside the original austenitic grains.

Fine shrinkage porosity, surrounded by narrow bands exhibiting a limited etching response, is evident in Figure 5. Further, an increased amount of non-metallic inclusions (manganese sulphide) and the bainite observed in these areas proves that these are the last solidified areas of enriched melt where the largest segregation can be expected.

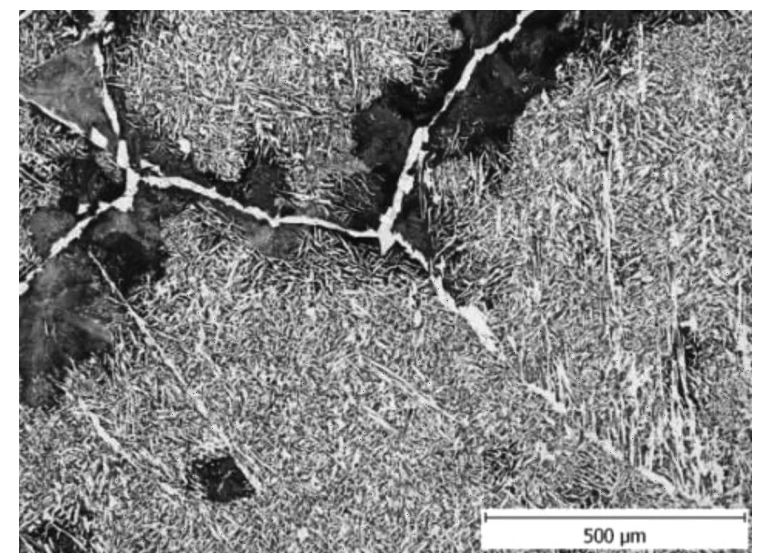

Figure 3: Detail of the microstructure in the area of columnar crystals Slika 3: Detajl mikrostrukture v področju stebrastih kristalnih zrn 


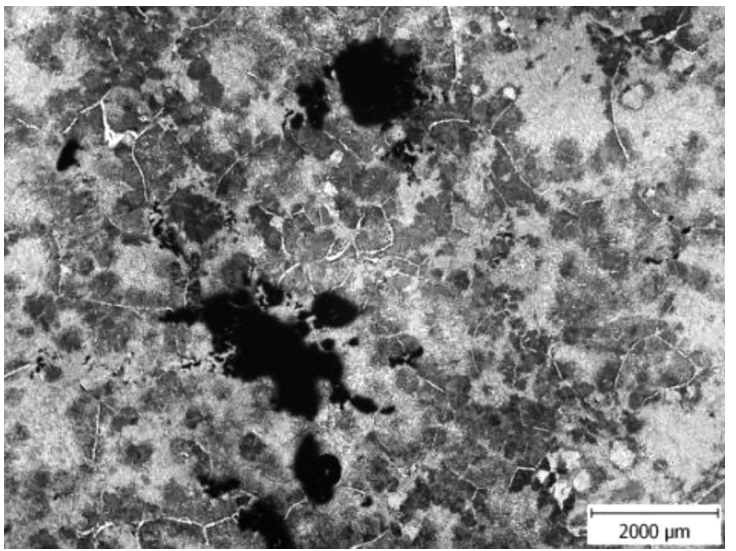

Figure 4: Microstructure in the axial area of the billet Slika 4: Mikrostruktura na sredini gredice

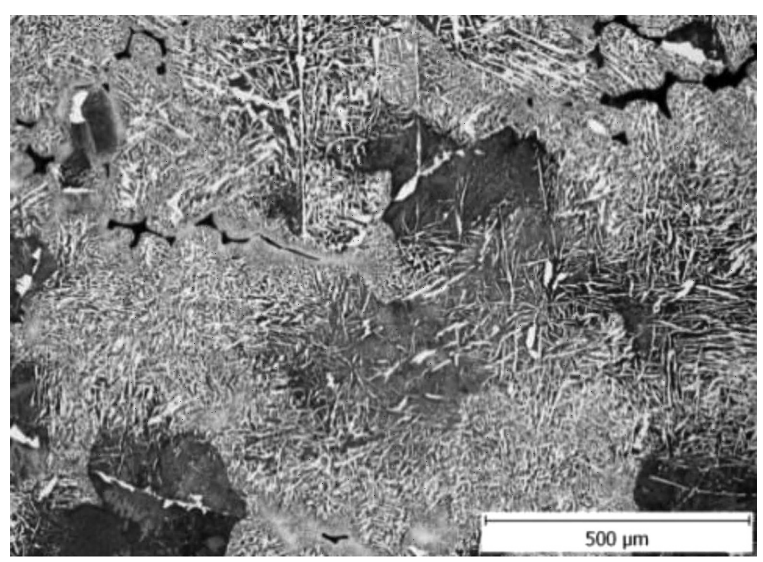

Figure 5: Detail of the microstructure in the axial area of the billet Slika 5: Detajl mikrostrukture na sredini gredice

Results of a semi-quantitative X-ray microanalysis of sample 4 are given in Table $\mathbf{2}$. When comparing them with the results given in Table 1, it is evident that the metal matrix in the studied area with a different etching response was enriched by all the evaluated substitution solutes and, in addition, a significant concentration of phosphorus was found here.

Table 2: Results of the EDX microanalysis - sample 4 Tabela 2: Rezultati EDX-mikroanalize - vzorec 4

\begin{tabular}{|c|c|c|c|c|c|c|}
\hline \multirow{2}{*}{ Analysis } & \multicolumn{7}{|c|}{ Analysed elements (wt. \%) } \\
\cline { 2 - 7 } & $\mathrm{Si}$ & $P$ & $\mathrm{Cr}$ & $\mathrm{Mn}$ & $\mathrm{Fe}$ & $\mathrm{Mo}$ \\
\hline 1 & 0.40 & 0.33 & 1.22 & 1.46 & 95.84 & 0.75 \\
\hline 2 & 0.35 & 0.19 & 1.30 & 1.33 & 95.96 & 0.87 \\
\hline 3 & 0.42 & 0.21 & 1.26 & 1.42 & 95.98 & 0.71 \\
\hline AVE & $\mathbf{0 . 3 9}$ & $\mathbf{0 . 2 4}$ & $\mathbf{1 . 2 6}$ & $\mathbf{1 . 4 0}$ & $\mathbf{9 5 . 9 3}$ & $\mathbf{0 . 7 8}$ \\
\hline STD & 0.08 & 0.08 & 0.07 & 0.08 & 0.08 & 0.08 \\
\hline
\end{tabular}

Note: AVE - arithmetic mean, STD - standard deviation

The microstructure of sample 5 (the axial part of the billet) with an increased fraction of pearlite adjacent to the shrinkage porosity is shown in Figure 6.

Similar to sample 4, bands with a different etching response were found in the surroundings of the shrinkage

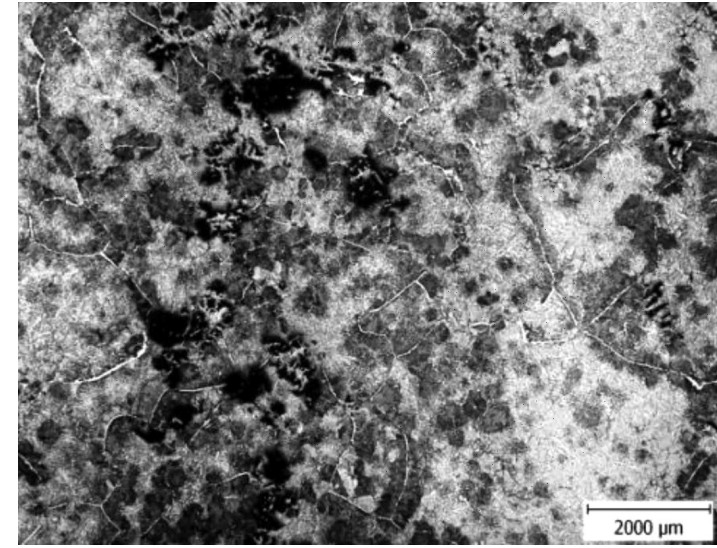

Figure 6: Microstructure in the axial area of the billet Slika 6: Mikrostruktura na sredini gredice

porosity where the microstructure was made of bainite, and a large amount of sulphide inclusions was observed, as seen in Figure 7.

In the case of sample 5, a semi-quantitative $\mathrm{X}$-ray microanalysis was also made and its results are given in Table 3.

Table 3: Results of the EDX microanalysis - sample 5

Tabela 3: Rezultati EDX-mikroanalize - vzorec 5

\begin{tabular}{|c|c|c|c|c|c|c|}
\hline \multirow{2}{*}{ Analysis } & \multicolumn{7}{|c|}{ Analysed elements $(w / \%)$} \\
\cline { 2 - 7 } & $\mathrm{Si}$ & $P$ & $\mathrm{Cr}$ & $\mathrm{Mn}$ & $\mathrm{Fe}$ & $\mathrm{Mo}$ \\
\hline 1 & 0.49 & 0.34 & 1.53 & 1.35 & 95.21 & 1.08 \\
\hline 2 & 0.55 & 0.22 & 1.27 & 1.49 & 95.75 & 0.72 \\
\hline 3 & 0.54 & 0.00 & 1.46 & 1.31 & 95.77 & 0.92 \\
\hline AVE & $\mathbf{0 . 5 3}$ & $\mathbf{0 . 1 9}$ & $\mathbf{1 . 4 2}$ & $\mathbf{1 . 3 8}$ & $\mathbf{9 5 . 5 8}$ & $\mathbf{0 . 9 1}$ \\
\hline STD & 0.03 & 0.17 & 0.13 & 0.09 & 0.32 & 0.18 \\
\hline
\end{tabular}

Note: AVE - arithmetic mean, STD - standard deviation

\section{SEGREGATION PARAMETERS}

On the basis of the X-ray microanalysis results, it was decided to carry out also a carbon and sulphur analysis of the micro-samples taken from individual

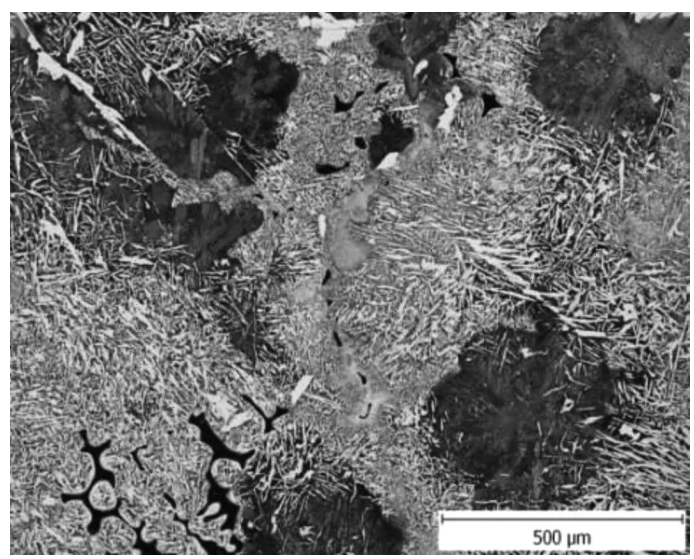

Figure 7: Detail of the microstructure in the axial area of the billet Slika 7: Detajl mikrostrukture na sredini gredice 


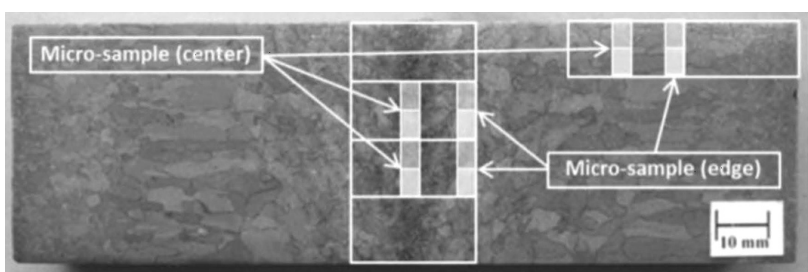

Figure 8: Positions of micro-samples taken for the combustion analysis

Slika 8: Položaji mikrovzorcev za analizo z zgorevanjem

areas of the macro-etching. Sample 2, sample 4 and sample 5 were chosen for a proper analysis. The samples were cut into the micro-samples for an evaluation of individual areas, as seen in Figure 8.

The analysis was carried out in an ELTRA CS 2000 combustion analyser and the results obtained for individual micro-samples are given in Table 4.

Table 4: Results of the combustion analysis of micro-samples Tabela 4: Rezultati analize z zgorevanjem mikro vzorcev

\begin{tabular}{|c|c|c|c|c|c|}
\hline \multirow[t]{2}{*}{ Sample } & \multirow{2}{*}{$\begin{array}{l}\text { Place of } \\
\text { sampling }\end{array}$} & \multicolumn{2}{|c|}{ Elements $(w / \%)$} & \multicolumn{2}{|c|}{$\begin{array}{c}\text { Average values } \\
(w / \%)\end{array}$} \\
\hline & & $\mathrm{C}$ & S & $\varnothing_{\text {carbon }}$ & $\varnothing_{\text {sulphur }}$ \\
\hline \multirow{4}{*}{2} & \multirow{2}{*}{ Edge } & 0.304 & 0.0083 & \multirow{2}{*}{0.301} & \multirow{2}{*}{0.0081} \\
\hline & & 0.297 & 0.0078 & & \\
\hline & \multirow{2}{*}{ Centre } & 0.300 & 0.0087 & \multirow{2}{*}{0.302} & \multirow{2}{*}{0.0087} \\
\hline & & 0.304 & 0.0086 & & \\
\hline \multirow{4}{*}{4} & \multirow{2}{*}{ Edge } & 0.269 & 0.0071 & \multirow{2}{*}{0.278} & \multirow{2}{*}{0.0074} \\
\hline & & 0.287 & 0.0077 & & \\
\hline & \multirow{2}{*}{ Centre } & 0.328 & 0.0101 & \multirow{2}{*}{0.347} & \multirow{2}{*}{0.0098} \\
\hline & & 0.365 & 0.0095 & & \\
\hline \multirow{4}{*}{5} & \multirow{2}{*}{ Edge } & 0.287 & 0.0089 & \multirow{2}{*}{0.285} & \multirow{2}{*}{0.0090} \\
\hline & & 0.283 & 0.0090 & & \\
\hline & \multirow{2}{*}{ Centre } & 0.318 & 0.0090 & \multirow{2}{*}{0.321} & \multirow{2}{*}{0.0098} \\
\hline & & 0.325 & 0.0105 & & \\
\hline
\end{tabular}

It is evident from Table 4 that the micro-samples taken from the centre show higher contents of carbon, by $0.045 \%$ of mass fractions (sample 4) and by $0.021 \%$ of mass fractions (sample 5), than in the area of columnar crystals (sample 2). It can be stated, in the case of sulphur, that its contents are in the range from $0,0074 \%$ to $0,0098 \%$ of mass fractions for all the micro-samples. On the basis of the obtained results, the micro-samples from the central area were evaluated by means of the chosen segregation parameters ${ }^{5}$ and their relations are given in Equations (1), (2) and (3).

$$
I h=\frac{S X}{X S}
$$

where $I h$ - is heterogeneity index, (-), SX - standard deviation, (-), XS - mean value, (-).

$$
I s=\frac{M A X}{X S}
$$

where $I s$ - is segregation index, (-), MAX - maximum value, (-), $X S$ - mean value, (-).

$$
k_{\mathrm{ef}}=\frac{1}{I s}
$$

where $k_{\mathrm{ef}}-$ is efficient partition coefficient, (-), Is segregation index. (-).

Chemical compositions of the analysed micro-samples were used for determining the segregation parameters, which were completed by the basic statistical parameters, and the results for carbon are given in Table 5, while the results for sulphur are in Table 6.

Table 5: Results of segregation parameters for carbon

Tabela 5: Rezultati parametrov izcejanja pri ogljiku

\begin{tabular}{|c|c|c|c|c|}
\hline \multirow{2}{*}{ Sample } & Place of & \multicolumn{3}{|c|}{ Segregation parameters } \\
\cline { 3 - 5 } & sampling & $I h$ & $I s$ & $k_{\text {ef }}$ \\
\hline \multirow{2}{*}{2} & Edge & 0.019 & 1.024 & 0.977 \\
\cline { 2 - 5 } & Centre & 0.020 & 1.020 & 0.980 \\
\hline \multirow{2}{*}{4} & Edge & 0.034 & 1.029 & 0.972 \\
\cline { 2 - 5 } & Centre & 0.094 & 1.115 & 0.897 \\
\hline \multirow{2}{*}{5} & Edge & 0.010 & 1.012 & 0.988 \\
\cline { 2 - 5 } & Centre & 0.048 & 1.044 & 0.958 \\
\hline
\end{tabular}

Table 6: Results of segregation parameters for sulphur Tabela 6: Rezultati parametrov izcejanja pri žveplu

\begin{tabular}{|c|c|c|c|c|}
\hline \multirow{2}{*}{ Sample } & \multirow{2}{*}{$\begin{array}{c}\text { Place of } \\
\text { sampling }\end{array}$} & \multicolumn{3}{|c|}{ Segregation parameters } \\
\cline { 3 - 5 } & Edge & 0.0695 & 1.0779 & 0.9277 \\
\hline \multirow{2}{*}{2} & Edge & \multicolumn{1}{|c|}{$k_{\text {ef }}$} \\
\cline { 2 - 5 } & Centre & 0.0962 & 1.0741 & 0.9310 \\
\hline \multirow{2}{*}{4} & Edge & 0.0422 & 1.0590 & 0.9443 \\
\cline { 2 - 5 } & Centre & 0.1519 & 1.1374 & 0.8792 \\
\hline \multirow{2}{*}{5} & Edge & 0.1108 & 1.0832 & 0.9232 \\
\cline { 2 - 5 } & Centre & 0.1639 & 1.1895 & 0.8407 \\
\hline
\end{tabular}

On the basis of the calculated segregation parameters from Tables $\mathbf{5}$ and $\mathbf{6}$, the following rows were determined. Individual substitutional solutes segregate in conformity with the decreasing value in the efficient partition coefficient $\left(k_{\mathrm{ef}}\right)$ :

- sample 2: Mo-Si-Mn-Cr

- sample 4: P-Mo-Cr-Si-Mn

- sample 5: P-Mo-Cr-Si-Mn

Considering the values of the efficient partition coefficient $\left(k_{\mathrm{ef}}\right)$, the phosphorus in sample 5 segregates extremely significantly, the phosphorus of sample 4 segregates significantly, while carbon, sulphur, silicon, chromium, molybdenum and manganese segregate into an interdendritic melt. Molybdenum segregates with the highest intensity $\left(k_{\mathrm{ef} .}=0.685\right)$ in sample 2 , phosphorus segregates with the highest intensity $\left(k_{\text {ef. }}=0.365\right)$ in sample 4, phosphorus segregates with the highest intensity $\left(k_{\mathrm{ef}}=0.169\right)$ in sample 5 , carbon segregates with the lowest intensity $\left(k_{\mathrm{ef}}=0.979\right)$ in sample 2 , carbon segregates with the lowest intensity $\left(k_{\mathrm{ef}}=0.935\right)$ in sample 4 and carbon segregates with the lowest intensity $\left(k_{\mathrm{ef}}=\right.$ 0.973 ) in sample 5 .

An identical order of segregation follows from the obtained values of the efficient partition coefficients $\left(k_{\mathrm{ef}}\right)$ 
and from the data index of element segregation (Is) when, in both cases, the process is finished by carbon.

\section{CONCLUSIONS}

A study of macro-segregations on the longitudinal sections of continuously cast billets $\varnothing 160 \mathrm{~mm}$ was made without the usage of the MEMS technology. The evaluation was aimed not only at a macro-structural analysis of the longitudinal section of a billet but also at an evaluation of the microstructure, a quantitative X-ray microanalysis (EDX) and an evaluation of the segregation parameters on the chosen samples. Based on the results of the structure characterisation, the following conclusions can be stated:

- macro-etching revealed three typical areas (the chill zone, columnar crystals and the central area of equiaxed crystals) of the structure of a cast billet. In the axial area, there was shrinkage porosity with a diameter of approx. $2 \mathrm{~mm}$. Local changes in the etching response in that area were explained as the consequence of the effect of the chemical segregation during the billet solidification.

- the microstructure of the whole section of the billet consisted of networks of allotriomorphic ferrite grains along the previous austenite-grain boundaries, needles of acicular ferrite and nodules of the pearlite component. Immediately under the billet surface and in the centre of the longitudinal section of the billet, higher fractions of pearlite were observed. This proved that carbonization occurred in these areas. In the under-the-surface areas, it was probably due to the reaction of steel with the cast powder. In the centre of the longitudinal section of the billet, the microstructural changes are connected with the effects of the chemical segregation during solidification.

- during the microstructural analysis of the axial area of the billet, bands with different etching responses, together with sulphide inclusions, were found in the surroundings of the shrinkage porosity. The last portions of the segregated melt were solidified in these areas. As a result of the chemical segregation, austenite decomposed into bainite in these areas.

- in the areas with a modified etching response, an enrichment due to all the substitutional solutes, including a significant increase in the phosphorus concentration, was proved with an X-ray microanalysis. Apart from phosphorus, a high degree of segregation was proved in the cases of molybdenum, chromium and manganese.

- on the basis of a metallographic and micro-analytic evaluation, a carbon analysis of the micro-samples taken from individual bands of the macro-etching was carried out by means of a combustion analyser to perform a complex evaluation.

- it is evident from the distribution of the maximum and minimum values of the segregation indexes (Is) of individual elements that the highest values were determined (for most of the analysed elements) in the centre of the longitudinal section of the billet. On the contrary, the lowest values of the segregation indexes (Is) of individual elements were found (for most of the analysed samples) in the area of columnar crystals. This confirmed the precondition that the highest tendency to segregation can be expected along the billet axis, while the lowest tendency to segregation can be expected in the area of columnar crystals and in the chill zone.

- it is obvious that phosphorus is the most segregating element because its value of the efficient partition coefficient $\left(k_{\mathrm{ef}}\right)$ is lower than for the other analysed elements. It was proved that the segregation index for phosphorus (Is) reached the highest values.

- the obtained results made it possible to describe and evaluate the material properties of the continuously cast billet $\varnothing 160 \mathrm{~mm}$, which can be used for a result verification and solidification-model development by means of numerical modelling.

\section{Acknowledgements}

This paper was carried out with the support of the project of Student Grant Competition, numbers SP2015/78 and SP2015/70.

This work was created at the Faculty of Metallurgy and Materials Engineering within Project No. LO1203 Regional Materials Science and Technology Centre Feasibility Program funded by the Ministry of Education, Youth and Sports of the Czech Republic.

\section{REFERENCES}

${ }^{1}$ M. Žaludová, B. Smetana, S. Zlá, J. Dobrovská, A. Watson, J. Vontorová, S. Rosypalová, J. Kukutschova, M. Cagala, Experiment study of Fe_C-O based system above 1.000 A degrees C, Journal of Thermal Analysis and Calorimetry, 112 (2013) 1, 465-471, doi:10.1007/s10973-012-2847-8

${ }^{2}$ M. C. Flemings, Solidification Processing, $1^{\text {st }}$ ed., McGraw -Hill College, New York, 1974, 364

${ }^{3}$ W. R. Irving, Continuous Casting of Steel, Cambridge University Press, (1993), 207

${ }^{4}$ K. Schwerdtfeger, Metalurgie des Stranggießens, Verlag Stahl und Eisen GmbH, Düseldorf, 1992, 640

${ }^{5}$ M. N. Gungor, A statistically significant experimental technique for investigating microsegregation in cast alloys, Metallurgical Transactions A: Physical Metallurgy and Materials Science, 20 (1989) 11, 2529-2533, doi:10.1007/ BF02666687 